\title{
Promoting the Image of Africa through Media: The Role of African Leaders (Case Study of Nigeria)
}

\author{
Chizirim Favour Zeph-Ojiako \& Blessing Winny Anakwuba \\ http://dx.doi./org/10.4314/ujah.v20i3.5
}

\begin{abstract}
Media is the mirror through which people see the outside world. Media is information and information, they say, is power. The role of media in the obnoxious depiction of Africa and its people, which is mainly business-oriented, cannot be overemphasized. Innumerable negative reports and exaggerated stories have been intellectually presented, discussed and debated on both local and international media platforms with very wide or large audiences. This has affected Africans, especially how they are perceived and treated in the outside world and this has in turn caused emotional and psychological distress for Africans. What worsen the situation is the nonchalance of African leaders in taking adequate measures to put a stop to this stereotypical and Afro-pessimistic media exposure. This is why this study after examining the role of the Western media in stereotyping Africa through the Agenda-setting theory, and the sad experiences of Nigerians and other Africans in the diaspora gathered through interview, suggested roles that her leaders can play in promoting and rebranding the image of Africa and Nigeria in particular, in order to restore her glory before it descends into new lows. This paper therefore, presents the extent of this unfortunate portrayal of Africa to the rest of the world, how deep this has affected Africa and Africans negatively, the reasons for this negative connotations with Africa, and why the time is now not only for Africa to show to the world its profound histories and beautiful stories impeccably but also to strategically control the
\end{abstract}


access and activities of researchers/ tourists/ media outlets in sensitive places within the continent. Also, how the African leaders can regain its image positively by promoting the real Africa to the world through Media.

\section{Introduction}

Media is a way in which people from different backgrounds and ethnicities communicate information to the rest of the world. Media is a vital source of communication. This is why media either it is printed, electronic or the web, according to Gauva and Nity (2017) is the only medium, which helps in making people informed. News is the most significant characteristic of media which is of paramount importance to one's social life. In this light, the Business dictionary (2019) described media as any communication channels through which news, entertainment, education, data, or promotional messages are disseminated. Media are communication outlets or tools used to store and deliver information or data.

Media is the eye through which the society sees beyond its immediate surrounding and this function of the media has been massively exploited by the Western Media in painting an age-long derogatory picture of Africa as a nation bedeviled with war, starvation, disease, corruption and economic holocaust, forgetting the many victories and successes recorded so far. Heavy media, often known as corporate or traditional media, has done a considerable damage to both Africa and its people. Inaccurate and gross generalizations of African realities can be easily qualified as crude stereotyping and downright essentializations (Mami, 2017). Poncian (2015) (as cited in Oguh, 2015), observed that during the $19^{\text {th }}$ and $20^{\text {th }}$ centuries, the European colonial powers created and disseminated negative images about Africa in order to justify their 
activities and domination of Africa. This they had done only to capture the attention of audiences and for some unexplained economic benefits. This was supported by Moeller (1999) who blames American media outlets for promoting crises and disasters using "formulaic reporting", sensationalism and references to American cultural icons in order to capture and hold the attention of audiences. She stated that the operating principle behind much of the news business is to appeal to an audience especially a large audience with large demographics for advertisers.

Some perpetrators of these acts claim that this media representation of Africa is to gain public compassion which will appeal to humanitarian organizations to send aids. Compassion can be defined as an empathetic and altruistic feeling for the pains and misfortune that another is experiencing as a result of the improper working of the society in which they found themselves. According to Nussbaum (as cited in Hoijer, 2003), compassion is a painful emotion occasioned by the awareness of another person's undeserved misfortune. She regards compassion as a complex emotion including such cognitive beliefs that the suffering of the other is serious, and that the suffering person does not deserve the pain. This makes the suffering person an innocent victim of some gruesome acts or circumstances. This simply means that compassion is both an affective and a cognitive reaction. Also according to Sznaider (as cited in Hoijer, 2003), public compassion originates in an abstract, theoretical and rational idea of humanity, not in religious charity. It is closely connected with the ideas of the enlightenment and the humanitarian movements that arose in the eighteenth and the nineteenth centuries, such as movements to abolish slavery, child labour, and so on.

Sznaider defines two perspectives on public compassion: one related to democratization processes in which equality is 
central, and the other related to the market society, in which an extending exchange of goods and services unintentionally also extends the moral concern for strangers. He also discusses the Marxist critique according to which compassion is "nothing other than the narcissistic desires of an exploitative bourgeoise to feel good about itself" (Sznaider, 1998). We certainly may or may not agree with Sznaider in his view on other issues, but his notion about the connection between public compassion and democratization processes is more reasonable. This totally corroborates Sharma's idea on humanitarian aids, Sharma (2017), noted that to be the target group of humanitarian communication is not necessarily experienced much differently from being the target group of any other kind of advertisement. This he said is not so surprising since humanitarian organizations operates today much like brands and speak to us as consumers just like any other brand will do and the fact that the humanitarian enterprise has become big business implies that it is increasingly difficult not to experience such enterprise as business as usual. He continued that while the modern version of humanitarianism, which emerged in the late $18^{\text {th }}$ century alongside the American Declaration of Independence and the French Declaration of the Rights of Man, has typically understood itself as something that is universal, a common focus in recent critiques of compassion, sympathy, and pity is the processes of politicization that seem central to the moral and affective practices of humanitarianism.

One major critique of the "politics" of compassion maintains that compassion is, in its very structure, an asymmetrical feeling that is typically directed downwards in social and geopolitical hierarchies. Thus these hierarchies may be reproduced once such hierarchies uphold the continuous forming of subjects and objects of compassion (Sharma, 2017).This is typical of the 
African experience, humanitarian organizations have done this to continue to announce and maintain their narcissistic presence in Africa even when the Western negative media representation of Africa has been met with what Moeller (1999) called Compassion fatigue. Thus, Oguh (2015) argued that Western media's viewpoint on Africa has outlived its usefulness.

In the following, compassion has to do with perceiving the suffering and the needs of distant others through media images and reports. Global compassion is then a moral sensibility or concern for remote strangers from different continents, cultures and societies. The discourse of global compassion takes place in the intersection between politics, humanitarian organizations, the media, and the audience/citizens (Hoijer, 2003). Since these media stereotyping of Africa have been met with compassion fatigue and enough profit has been made from the business intensions of the Western media, it is high time the western media channeled its energy to some other areas so that Africa can move on as it dusts off the stench of several years of negative exposition. These necessitated the need for this qualitative study, enhanced through responses gathered from interviews with Africans in the diaspora, and proffering solutions which the African leaders and Africans also can join hands together to implement for a better Africa.

\section{Theoretical Framework}

This study is examined using the agenda setting theory which was propounded by Max McCombs and Donald Shaw in a study on the 1968 American presidential election, but the beginning of agenda setting theory can be traced as far as 1922, when Walter Lippmann expressed his concern on the vital role that mass media can play in influencing the setting of certain image on the public's mind even though he never used the term agenda setting theory (Zain, 2014). 
This theory describes the potency of the news media in influencing the importance people placed on the topics of the public agenda. According to the Communication theory (n.d.), the media focuses on how people should think about the nature of the issues. Thus, sensationalization of news reports may happen to bring in the interest of the audience. In fact, media wants to grab attention and implant thoughts in people's minds about some serious issues, that is why media turn certain issues viral. It asserted that the main concept associated with this theory is gate keeping. Gate keeping is in charge of and has control of the selection of content discussed in the media and it is assumed that the public cares mostly about the product of media gate keeping. The news media decides 'what' events to broadcast and show through the media 'gates' on the basis of 'newsworthiness'. This is what the media has exploited thus imprinting certain images in the minds of audience and viewers about Africa and because media audiences do not just receive information passively but are actively involved, often unconsciously in making sense of the message within their personal and social contexts and this has caused stereotypical perception of Africa and Africans in general which has not augured well with the continent. Indeed, the popular stereotypes of Africa in Western media have essentially turned the continent into a one story issue which resulted in the paucity of positive stories about Africa except stories of war, danger, darkness, violence, poverty, disease, and hopelessness. Michira (2002) also stated that Africa is often portrayed as a homogenous entity comprising uncivilized and heathen peoples who are culturally, intellectually, politically, and technically backward or inferior. 


\section{Some stereotypical Experiences of Africans}

Africa as a continent has been failed by media within and outside the continent. To most people outside the continent, Africa is a desert with plenty animals and few humans who live in extreme poverty. This without an iota of doubt explains why Africans abroad including the co-researcher are often asked appalling questions, and also receiving unjust and unfair treatments all over the world.

During the co-researcher's studies in China, she witnessed different sorts of feelings and treatments from the Chinese people because she is African. Some of the Chinese people exhibit gross and despicable reaction towards Africans when they are sited close to them on public buses, trains, airplanes, markets, parks and so on; they cover their noses, some would prefer to stand rather than sit close to an African just for the fear of contracting diseases. Other times, the brave ones would ask such questions as; what does a zebra look like? You do not have houses in Africa right, only huts?

One African student studying in the northern part of China bitterly narrated her ordeal to the researcher how a young Chinese boy boldly approached her to ask her whether or not she could eat Chinese sand? She was lost. How can one possibly eat any sand let alone Chinese sand? She asked herself. As he saw the outright bewilderment and unhidden confusion on her face, he quickly apologized for his somewhat ignorance with further explanation that they usually see African children on CGTN (a popular Chinese broadcasting television network) eating sand because they lacked food and water. She went on complaining about how she almost developed high blood pressure and self-hate at the first few months of her arrival in China until she eventually got used to these reactions after some consolation from her friends who had been in 
the country before her. One cannot blame the Chinese people in this scenario for their ignorance towards Africa because they were expressing what the media fed them.

Another African student studying in the southern part of China interviewed for the cause of this research also lamented on how he usually hear Chinese people (kids included) call him 黑鬼heigui (black devil). At first, when he newly arrived China, he did not notice the name was addressed to him, after a few months as he moved around to more places he noticed some kids pointed at him while saying 黑鬼heigui, that was when he realized he was the 'black devil'. He was so curious to understand why a fellow human being would refer to him as a devil, a Chinese friend explained to him how Africa is full of thieves, kidnappers, thugs and all other sorts of criminals, therefore, to an average Chinese it is not safe to be around an African because they are devils as depicted on media outlets. He complained that his greatest annoyance was how these Chinese who have never travelled outside their hometowns would ignorantly have a strong common belief about a whole continent without a visit. He further explained that after the explanation from a Chinese about the reason for calling Africans 'black devils', he did a research on how Chinese see Africans, that was when he came across the application called 抖音(douyin), an application for creating short videos. According to him, he saw horrible videos and images that made him shed tears, hundreds of appalling images shared by Chinese that have visited Africa which made him ask himself a lot of questions such as; how African government can allow foreigners not only Chinese to go to sensitive places and take sensitive pictures to show to the rest of the world. It is not hidden that some people in some parts of the African continent still move around naked, it is the job of the government of such countries to protect their nakedness by making strict rules guiding 
them such as prohibition of foreigners from visiting such places, even if they do, phones and cameras should be restricted. To name a few, he complained about the most disgusting video of all, which was a video of a Chinese man that visited one of those African countries and was allowed to abuse two teenage girls by grabbing their breasts while posing for the camera, he uploaded those horrible pictures on the application called Douyin for the whole world to see with the caption, "This is Africa". "How can anyone after watching such despicable post respect anyone from such continent?' he asked. He continued that this made him realize how the world sees Africa and how bad the media has reshaped her image.

During an interview with a Ghanaian studying in the UK, she admitted that because she is African, everyone assumed she was on a scholarship or a daughter of a politician because they believe that Africans are too poor to study abroad let alone study in one of the most prestigious institutions in the UK.

In addition, another Nigerian male studying in Germany also lamented that whenever he introduces himself to some new friends or classmates as a Nigerian, he often gets questions such as 'hope your family is okay because of Boko Haram'? Have the Chibok girls been released? Are you here on asylum to get away from Boko Haram? Many constantly reminded him of how he made the right choice by leaving Nigeria because it is an unsafe place to be; as if Nigeria is the most dangerous place in the world. These and many more are the daily experiences of Africans in the outside world.

\section{The Way Forward for Africa}

With the colossal wreck or damage the misrepresentation of Africa has created towards this lovely continent and its people, and the 
direct or indirect negative socio-economic impacts, giant steps must be taken to restore the image of this graciously endowed continent before we descend into new lows. Long time exposure to denaturalizing and stereotypical contents about Africa by the media industry deliberately demeans and ridicules one's sense of being as Chimamanda Ngozi Adichie quoted in her TEDx talk in 2009 , that stories can break the dignity of a people. She also added that "Africa is a continent full of catastrophes, there are immense ones and depressing ones, but there are other stories that are not about catastrophes. And it is very important, it is just as important to talk about them." Therefore, it is high time Africa and her leaders rose from its slumber and took the bull by the horn by rewriting her stories by herself and not continuing to allow the Afropessimistic Western media to continue with its one-sided story. Some ways by which this herculean task can be done are discussed below.

\section{Social Media}

Social media has not only been used as a means of socializing and connecting with people but has also acted as a strong force of influence on any matter of concern round the world. It has yielded maximum results in pursuing causes that have bettered the lives of the masses, to put the government of the day on track in various climes, to fight injustices, etc. Thus Africans can use the same weapon to demean, mortify and annihilate completely the negative pictures that Western media has painted of Africa over the centuries. Africans have been known to be internet and social media savvy because the number of Africans who use the internet has increased from 4,514,400 in 2000 to $453,329,534$ in 2017, giving Africa an internet penetration of $35.2 \%$ and African social 
media users have also increased that at the end of 2017 about 177,005,700 were on Facebook (Mkono, 2018).

Africa can take the world by storm if every social media user utilizes every opportunity to paint a different "beautiful" picture of Africa especially bloggers, entertainers and well known social media influencers. Mkono (2018) corroborates this by stating that social media presents a powerful platform for creating multiple stories about Africa and that by embracing the accessibility of modern technology, African bloggers and commentators are using Facebook, Youtube and other platforms to undermine longstanding "Afro-pessimistic" stereotypes, the backward continent characterized by strife and poverty. Also, by giving ordinary people the space to share their everyday experiences, African bloggers are capturing positive "human moments". These moments of joy, play, celebration, love and human interaction, create new narratives of Africa.

The social media should be replete with diverse and multiple pictures of the uniqueness and the beauty of the African continent; the everyday playful and smiling African child, the edifices, roads, thriving agricultural setting, beautiful green pasture, the classy and luxury lifestyle of Africa and the kindness and humanity displayed every day. This, to a large extent will reduce the dangers of a single story as Chimamanda Ngozi Adichie put it at her TEDx talk where she emphasized that multiple stories are important stressing that " the single story creates stereotypes, and that the problem with stereotypes is not that they are not untrue, but that they are incomplete. They make one story become the only story" she said. Also, that 'Stories can break the dignity of a people, but stories can also repair that broken dignity' (Adichie, 2009). This function can be perfectly done using the social media as according to Mkono (2018), social media presents a powerful 
platform for creating more plural stories about Africa even though the Afro-positive turn should not be about whitewashing and romanticizing Africa but should be about challenging the simplistic nature of Afro-pessimism, through introducing multiple and complex images about the continent and its people. The federal government of Nigeria can sponsor jingles and orientation programs that can educate bloggers and citizens alike on the right content for this venture.

\section{Hash Tags}

Over the years, especially in this era of internet and social media, many causes have been brought to limelight, fought for and won by using captivating and simple "Catch-phrases" or words which relate to the issue being championed, these words are called hash tags, written with the character \# attached to it. Merriam Webster dictionary defined a hash tag as a word or phrase preceded by the symbol \# that classifies or categorizes the accompanying text (such as a tweet).

According to Merriam-webster.com, social media has made the hash tag a ubiquitous part of internet culture, starting with Twitter and expanding to other sites. For instance, even a layman understands the phrase "Bring Back our Girls" (BBOG) which was used and still a common phrase on the media concerning the abducted Chibok school girls. "Yes, we can", America can be great again", "Sex for grades", these are few of the catch-phrases that are very popular both in Africa and in the rest of the world. Thus, such catch-phrases can be coined towards Rebranding African nations and letting the world see the beauty of the African continent. This is because McDonald (2017) stated that hash tags help to increase one's social media presence as they make one's content viewable by anyone who has interest in that hashtag as it 
goes beyond just one's followers, furthermore, they also help to build a brand for a business or for someone by engaging with customers and joining the conversation about what is trending. And if one participates in high-traffic conversation by discovering the biggest trending topics, one is more likely to gain great visibility and the more visibility one gets, the more likely such one is able to create a larger audience and a larger audience exponentially increases the likelihood of fresh leads for business. Thus hash tags are very effective tools that can be used to re-write the place Africa occupies in the Western media and in the minds of people around the globe. For instance, the phrase 'Nigeria; Good people, Great nation' was introduced in 2009 by the then minister of information and culture, Prof. Dora Akunyili, for the rebranding project of Nigeria which painted a beautiful picture of Nigeria as a beautiful nation with hardworking citizens. Such jingles and catch phrases help to rebrand and re-orientate the outside world about Africa (Muozoba, 2009).

\section{Government Regulation and Control}

The United States of America which is considered one of the most developed and powerful countries in the world witnesses gun violence every day. According to Brady (2019), every day, about 310 people are shot in the United States, among which 100 people are shot and killed. A lot of people have also died in knife attacks in the UK yet none of these countries have been marked/branded 'unsafe', and one barely sees or reads such on the news. For instance, Hoijer (2003) noted that in the recent Afghanistan War, American authorities mounted pressure on the media to refrain from reporting about civilian casualties and sufferings in order not to adversely affect the public support for the bombings. The chairman of CNN instructed the staff that if such news were going 
to be broadcast they should balance the reporting of victims in Afghanistan with reminders to the audience of the victims of the terror attack on World Trade Centre and the Pentagon (Ottosen, 2002). As indicated by a study of New York Times also, the press seemed to have followed the recommendations, Björnemyr \& Wahlqvist, (as cited in Hoijer, 2003).This clearly shows that other parts of the world have regulations and control for what is published or broadcast but Africans on the other hand (especially the leaders) wash their dirty linen in public view mostly for personal reasons. People so much believe what they see in the news, they only know what you show them. China for instance, despite its massive economic growth still have 30.4 million people living in poverty according to Forbes (n.d.), most of the poor in China live in the country side. Their farmland may be semi-desert and homes carved into a mountainside instead of along city streets. United States anti-poverty nonprofit organization the Borgen Project says on its blog as quoted by Jennings (2018), "Tall glassand-steel skyscrapers loom over gritty, crumbling slums." National level booms in infrastructure development may have missed the villages where impoverished Chinese live. Schools lack the technology or qualified teachers expected in urban classrooms, and business owners see little point in locating factories in places where infrastructure lags". None of these are shown to the rest of the world because of some government regulations on media. Therefore, it is pertinent for African leaders to put some measure of restriction on what or not the media can have access to and broadcast for the world to see.

\section{Recommendations}

Promoting the image of a nation or country lies solely in the hands of its leaders. A leader not only leads but also guides, influences, 
protects and promotes the interest of its people. This is why Gamelearn (2016) says that a leader must be at the forefront to lead and guide his/her people until the desired goal is reached. A leader protects its territory which he/she leads, by promoting its image to the world.

Before China became popular to the world through its advanced engagement and expertise in technology, China was already known to the rest of the world by promoting an integral part of her culture through media which is martial arts. This aroused the interests of people to visit China to witness this amazing display of strength which is not only energetic and lively but also quite entertaining. Until the co-researcher visited China, she always thought that all Chinese people were physically strong and good in martial arts because that was the image the Chinese government and its media painted of the country to the rest of world, which had a great positive impact on how the rest of the world see China. In other words, what you show the world is what they will know. Therefore, African leaders can restore the image of Africa to the world by promoting its beautiful nature for the rest of the world to see and appreciate. There are gazillion of things to be proud of in Africa. To name a few; Nigeria is famous for its diverse cultural heritage and natural tourist sites which when properly promoted and exhibited for the world to see will attract positive vibes to Africa; tourism, foreign direct investment and great partnerships. Ghana previously known as the "Gold of Coast" is fascinating with rich historical background, because of its wealth in natural resources, especially gold. Ghana is also known as a country with outstanding economy. In the recent years, Ghana has attained rising human capital development and rapid economic growth. It has been named one of the fastest growing economies in the entire Africa and ranked among the top ten countries in the 
world with a rapidly growing economy (Uwa, 2018). Kigali in Rwanda, on the other hand, has been known to be one of the cleanest cities in the world and an emerging technology hub (burdie.com, 2019). In addition to these, African leaders should create and air programs on television and social media to celebrate and promote incredibly talented Africans such as William Kamkwamba, a Malawian teenager who at the age of 14 taught himself how to build a windmill out of junk and bring power to his village. He then went on to build a second, larger windmill to power irrigation pumps. He did all these from books he read from the library (TED, 2017). Onoride Reginald Aziza the Nigerian student who bagged 3 first class degrees including one from Cambridge University at the age of 23, Dokosi (2019), and the last but not the least is a young man in Anambra state who built a power generating set that is hydro-powered from junk also. The world should know about these African geniuses.

\section{Conclusion}

Over the decades, many negative stories have been told about Africa through diverse media; stories of war, crimes, hunger, diseases, violence etc, but hardly does one hear her good and inspiring stories. This has led to the very degrading and unfair treatments meted to Africans everywhere in the world; from travel bans, embarrassing suspicions, isolations, unwarranted arrests, and in some cases, loss of lives, etc, these in turn result to psychological and emotional trauma, depression, self-pity, low self esteem and so on. This vicious cycle continues. What makes it unfortunate is that African leaders do little or nothing to change the narrative for Africa, even in some cases when loss of lives is involved forgetting that none is without some dirty linen except that you choose whether to air them in public view. 
This paper therefore, presents the extent of this unfortunate media portrayal of Africa to the rest of the world, how deep this has affected Africa and Africans negatively, the reasons for these negative Afro-pessimism, and why the time is now not only for Africa to show to the world its profound histories and beautiful stories impeccably but also to strategically control the access and activities of researchers/ tourists/ media outlets in sensitive places within the continent. Lastly, how the African leaders can regain our image positively by promoting the real and beautiful Africa to the world through Media.

\section{Chizirim Favour Zeph-Ojiako}

Department of Chinese Studies

Nnamdi Azikiwe University, Awka

ojiakoiruoma@yahoo.com

\&

\section{Blessing Winny Anakwuba}

Ekwueme Centre for

Multidisciplinary Research

Nnamdi Azikiwe University, Awka

anakwubawinny@gmail.com

\section{References}

Adichie, C. (2009).The Danger of a Single Story. Retrieved from https://www.ted.com/talks/chimamanda_adichie_the_dange r_ofa_single_story/transcript?language $=$ en

Brady united (n.d.). The facts that make US act. Retrieved from https://www.bradyunited.org/key- statistics

Business dictionary online.(n.d.). Retrieved from http://www.businessdictionary.com

Communication theory (n.d.). Agenda setting theory; Maxwell 
McCombs \& Donald Shaw. Retreived from https://communicationtheory.org

Dokosi, M. E. (2019). Heard of the Nigerian student who bagged 3 first class degrees including one from Cambridge University at age 23? Retrieved from https://face2faceafrica.com/article/heard-of-the-nigerianstudent-who-bagged-3-first- class-degrees-including-onefrom-cambridge-university-at-age-23?

Gamelearn (2016, December 1). What is Leadership?[Blog post].

Retrieved from https://www.game-learn.com/what-isleadership-ways-to-define/

Gaurav, S. \& Nity, P (2017). Role and impact of media on society. A sociological approach with respect to demonetization. Impact: International Journal of Research in Humanities, Arts and Literature. Vol. 5 (10). Pp. 127-136.

Hoijer (2003). The discourse of global compassion and the media. Media and Communication, Department of Humanities, Örebro University, birgitta.hoijer@hum.oru.se

Jennings, R.(2018). Despite China's fast-growing wealth, millions still remain poor. Retrieved from https://www.forbes.com/sites/ralphjennings/2018/02/04/wh y-tens-of-millions- remain-poor-in-china-despite-fastgrowing-wealth/amp/

Mami, F. (2017). De-stereotyping African Realities through social media in Chimamanda Ngozi Adichie's Americanah and Belkacem Meghzouchene's Sophia in the White city. Post colonial Interventions. Vol.2 (2).

Market Business News (n.d.). What is media? Definition and meaning. Retrieved from https://marketbusinessnews.com/financial-glossary/mediadefinition-meaning/ 
Mac Donald, J. (2017). The importance of hash tags: know where, why and how to use them. Retreived from https://www.business2community.com/socialmedia/importance- hashtags-know-use-01837644/amp Michira, J (2002) Images of Africa in the Western Media.

[accessed online 10.10.15]

http://www.teachingliterature.org/teachingliterature/pdf/multi/ images_of_africa_michira. pdf

Mkono, M. (2018).Changing the African narrative through social media platforms. The University of Queensland.theconversion.com (18/10/19).

Moeller, S (1999) Compassion fatigue. How the media sell disease, famine, war and death. New York and London: Routledge.

Muozoba C. (2009). Good people, great nation. Nigeria world. Retrieved from https://nigeriaworld.com/articles/2009/jul/022.html

Oguh C. (2015). The representation of Africa in western median: Still a $21^{\text {st }}$ century problem.

https://www.researchgate.net/publication/292141961

DOI: $10.13140 /$ RG.2.1.3984.2326

Ottosen, R. (2002) Pressfriheten under press after 11. September (The Freedom of the Press Under Pressure After September 11th). Oslo: NorskRedakørføreningsÅrbok 2001.

Sharma D. (2017).Doing good, feeling bad; Humanitarian emotion in crisis. Journal of Aesthetics and culture.Vol. 9, (1) TED (2017).William Kamkwamba; Inventor. https://www.ted.com/speakers/william_kamkwamba

Uwa, F. (n.d). 10 reasons Ghana is the coolest country in the world. Retrieved from https://buzzghana.com/10-reasons-ghanacoolest-country/\#

Zain, N.R.M. (2014). Agenda setting theory. Retrieved from https://www.researchgate.net/publication/321698436 